Article

\title{
Evaluation of the Brake's Performance Dependence Upon Technical Condition of Car Tires as a Factor of Road Safety Management
}

\author{
Olga Orynycz ${ }^{1, * \mathbb{D}}$, Karol Tucki $\left.{ }^{2, *} \mathbb{(}\right)$, Andrzej Wasiak ${ }^{1} \mathbb{1}$, Robert Sobótka ${ }^{2}$ and \\ Arkadiusz Gola ${ }^{3}$ (D) \\ 1 Department of Production Management, Bialystok University of Technology, Wiejska Street 45A, \\ 15-351 Bialystok, Poland; a.wasiak@pb.edu.pl \\ 2 Department of Production Engineering, Institute of Mechanical Engineering, Warsaw University of Life \\ Sciences, Nowoursynowska Street 164,02-787 Warsaw, Poland; robert_sobotka@sggw.pl \\ 3 Department of Production Computerization and Robotization, Faculty of Mechanical Engineering, Lublin \\ University of Technology, Nadbystrzycka 38 D, 20-618 Lublin, Poland; a.gola@pollub.pl \\ * Correspondence: o.orynycz@pb.edu.pl (O.O.); karol_tucki@sggw.pl (K.T.); Tel.: +48-746-98-40 (O.O.); \\ $+48-593-45-78$ (K.T.)
}

Received: 30 October 2019; Accepted: 16 December 2019; Published: 18 December 2019

\begin{abstract}
The social cost, as one of the factors determining sustainability of socio-economic development, is strongly dependent upon a number of casualties and mortality in road accidents. The condition of car tires appears to be one of the important factors determining the occurrence of accidents. The vast majority of vehicles are tested every year at vehicle inspection stations. One of the elements affecting the result of the technical condition test and basically the quality of vehicle braking is the technical condition of the tires. Their technical condition is a very important factor responsible for the quality of acceleration, braking, maintaining, or changing the direction of driving. As a consequence, it has a significant impact on road safety. The aim of the study is to examine the impact of tires on the results of tests performed at a vehicle inspection station. The study presents the results of bench measurements of the impact of selected features of tire condition of two vehicles during routine periodic inspections at a vehicle inspection station (VIS). The focus was on an attempt to assess the impact of inflation pressure, age, and tire tread wear on the braking process. The technical studies performed might be a source for legal steps assuring better management of road safety. It can also be expected that the tire choice and condition may affect fuel consumption, and therefore the amount of energy consumed by the road transport.
\end{abstract}

Keywords: periodic inspection; diagnostics; vehicle inspection station; road safety; automotive accidents

\section{Introduction}

The dynamic development of global economy and the globalization of automotive sectors require a multi-dimensional view [1,2]. Increased public awareness of the issues of reducing $\mathrm{CO}_{2}$ emissions has accelerated work on the development of electromobility $[3,4]$ and biofuels $[5,6]$. One of the most important parts of car engineering is the tire [7,8]. The contemporary approach in its design includes both issues related to process management $[9,10]$, the use of new technologies in the scope of applied design tools and construction materials [11-13], as well as issues related to recycling [14-16] and utilization $[17,18]$. However, the most important determinant in its design and use is the provision of security $[19,20]$. 
European roads remain the safest in the world [21,22]. In 2018, around 25,100 fatalities on the road $[23,24]$ were reported in $28 \mathrm{EU}$ Member States. This indicates a decrease of $21 \%$ compared to 2010. In 2017, the average mortality rate in 28 EU Member States was 49 road deaths per 1 million inhabitants, a $1 \%$ decrease compared to the previous year. This means that achieving the target of halving the number of road fatalities by 2020 is unlikely. Therefore, strong and well-targeted efforts are needed at all levels and in all sectors.

Poland is among the countries with one of the highest accident rates [25,26]. According to the police statistics, almost 31,674 road accidents occurred in 2018. As stated, technical failure of the vehicle was the direct cause of 108 road accidents (including more than $24.1 \%$ "technical deficiencies" in tires) [27]. Unfortunately, no statistics are published that would include any indirect impact, not only of deficiencies, but also the generally understood technical condition of tires as well as the application of manufacturers' recommendations regarding their proper handling. In order to make it easier for the average user to choose tires for their vehicle, the European Union introduced the labeling requirement for tires manufactured after 30 June 2012, i.e., the manufacturers must provide three tire properties: Fuel efficiency, wet grip, and external noise (class and result in $\mathrm{dB}$ ) [28].

In addition, the European Commission has introduced regulations that mandate the installation of a tire pressure monitoring system in every new car. The system called TPMS (tire pressure monitoring system) must be on the list of equipment for every car, regardless of make and model. These regulations are to contribute to increased safety, reduced fuel consumption, and reduced emissions of harmful substances $[29,30]$.

The vast majority of vehicles are tested every year at the vehicle inspection stations [31,32]. One of the basic tests is checking the technical condition of the braking system [33,34] and one of the elements influencing the result of the technical condition test, and basically the braking quality of the vehicle, is the technical condition of the tires [35]. The tires are in the so-called 'frontline' of the vehicle's braking system (wheel-to-road contact) [36]. It can therefore be assumed that their technical condition is a very important factor responsible for the quality of, among others: Acceleration $[37,38]$ braking [39], maintaining or changing the direction of driving [40,41], and consequently affects road traffic safety $[42,43]$.

The most important factors related to tires, which affect critical situations arising during road traffic, are degree of wear of tires [44], internal pressure in tires [45], size and type of vehicle load, and driving technique [46,47]. During the periodic review of the technical condition of the vehicle, the diagnostician is obliged to check the condition of the tires. The minimum tire tread depth is $1.6 \mathrm{~mm}$. The tire tread below $2 \mathrm{~mm}$ is not able to drain rainwater effectively, which can result in the vehicle slipping. The tires should not be cracked. Tires with the same tread structure must be mounted on one axle. Tire manufacturers often determine internally the tread depth, after which the tires are changed, regardless of their technical condition and compliance with statutory standards.

The degree of tread wear is particularly important when driving on wet surfaces $[48,49]$. The lower the tread pattern, the less resistant the tire is to the hydrodynamic slip [50], which causes a rapid reduction of the tires' adhesion to the surface due to the water wedge [51,52]. This is a dangerous phenomenon that causes the loss of vehicle stability in all directions [53]. In Polish road conditions, this is a phenomenon often encountered due to road ruts occurring on roads and stagnant water in them [54]. Considerable wear of the tire tread also causes the deterioration of its strength properties (among others, due to the progressive aging of the rubber and the carcass) during normal operation $[55,56]$. At the same time, its resistance to mechanical damage results from extreme conditions caused by, e.g., external factors such as unevenness and mechanical damage of roads, litter such as small elements of exhaust systems, other small parts of vehicles, or other objects left on roads by other users [57]. Each tire is constructed for a specific vehicle load, with the internal pressure specified by the manufacturer [58]. Reducing the pressure below the recommended level results in increased drift, especially when using older tires (with a higher profile), which in turn results in poorer vehicle drivability, makes the vehicle more susceptible to side-drift, and can lead to accidents in critical situations $[59,60]$. 
Vehicle manufacturers also specify vehicle speed limits for the tires concerned. The use of tires with too low a speed index can lead to significant radial deformations of the tire when driving at high speed [61]. In extreme situations (high speed, significant tire wear, age) the use of tires with too low a speed rating may even lead to a burst $[62,63]$. Practice shows that, in the case of loading the vehicle (without exceeding the permissible static load values for the whole vehicle), tire overload may occur in situations of incorrectly distributed load, driving at curves with excessive speed, driving over large irregularities, e.g., curbing with excessive speed [64]. The tire overloads occurring at the time can cause (apart from excessive and uneven wear) the rapid heating of the tire resulting in its stratification, refraction of the carcass causing it to lose strength, and in extreme cases, cracks or coming off the rim, resulting in a loss of vehicle stability [65].

Car segments (or classes) are divided into as many as 10 categories and are marked with the letters of the alphabet [66,67]. The lower the letter, the lower the vehicle class. Interesting in the context of the division into classes is that some cars of different classes are built on the same floor plate with the same engines and even suspension. The differences are visible in the body shape and the price. Class $\mathrm{A}$ and B cars are usually hatchbacks, which does not exclude the presence of sedans and station wagons in this group. In class A, there are city cars characterized by small dimensions, and most often only three doors (with a tailgate). Due to their construction, they are usually economical cars, characterized by low fuel consumption. Vehicles of this class are usually equipped with small engines generating low power. Due to technical characteristics, Class A cars do not work well on extra-urban routes, in particular on highways. Class B is more versatile than A. They are city cars, but they also perform well on extra-urban routes. They offer more space than Class A cars. Class $C$ has a wide variety of types. Therefore, we are dealing with hatchbacks, sedans, station wagons, and liftbacks. In many cases, the car model has all three body types, e.g., Toyota Corolla. Class $\mathrm{C}$ is the link between urban $\mathrm{B}$ and extra-urban D and has moderate features of both classes. In the case of higher classes (D, E), the variety of body types drops significantly. Most cars of these classes are offered in the sedan version, although in the D class, there are also station wagon versions. They are not economical cars. Engines with a capacity of at least 1.6 liters for gasoline and 2 liters for diesel require more fuel than class B and C. Segment $\mathrm{E}$ is for comfortable, well-equipped cars. In this class, it is rather difficult to find an engine with a capacity of less than 2 liters and power below $130 \mathrm{HP}$ (Horsepower). Category F applies to luxury cars, including limousines. Sports cars and so-called G-class super sport cars have bodies of various shapes, although they can most often be described as coupes. Other classes are typically associated with bodywork and technical characteristics. These are class $\mathrm{H}$ (convertibles), I (off-road cars including SUVs - Sport Utility Vehicle), and K (minivans).

\section{Materials and Methods}

\subsection{Tire Size Depending on the Vehicle Weight}

The information concerning the technical parameters of tires was obtained from the catalogs of car manufacturers [68-73] and the catalogs of companies dealing in the production and trade of tires [74-79].

Figures 1 and 2 summarize the information for the most popular models of passenger cars on the automotive market (from segment $\mathrm{A}$ to segment $\mathrm{E}$ ) with the basic types of tires recommended by the manufacturers. The starting parameter is the permissible gross vehicle weight (PGW - Permissible Gross vehicle Weight). The values presented refer to models with the smallest engine offered on the market for a given vehicle and with basic equipment.

As can be seen from the diagrams, the width of the used tires increases significantly with the increase of the PGW of the vehicle. One of the reasons for this dependence is the necessity to prevent unit pressure on the tire from being exceeded. There is also a clear tendency to lower the tire profile with the increase of the vehicle's PGW. 
The width of the tires in the PGW function of the vehicle

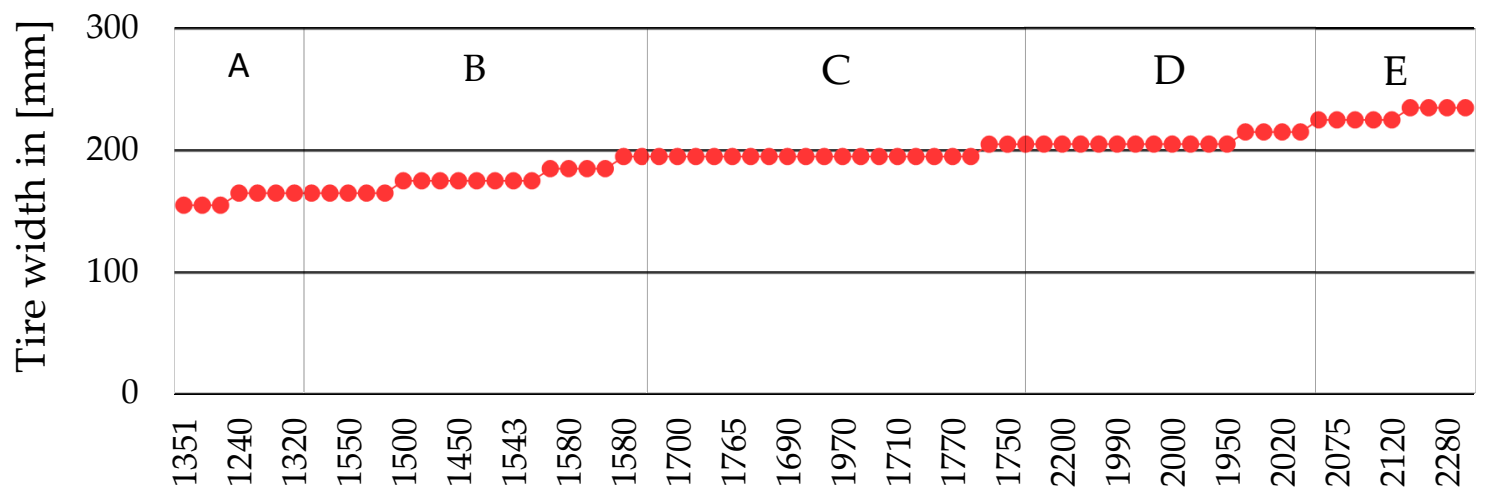

PGW of the vehicle [kg]

Figure 1. Widths of tires applied, depending on the permissible gross vehicle weight (segment $\mathrm{A}$ to segment E); PGW - Permissible Gross vehicle Weight.

\section{Tire profile in the PGW function of the vehicle}

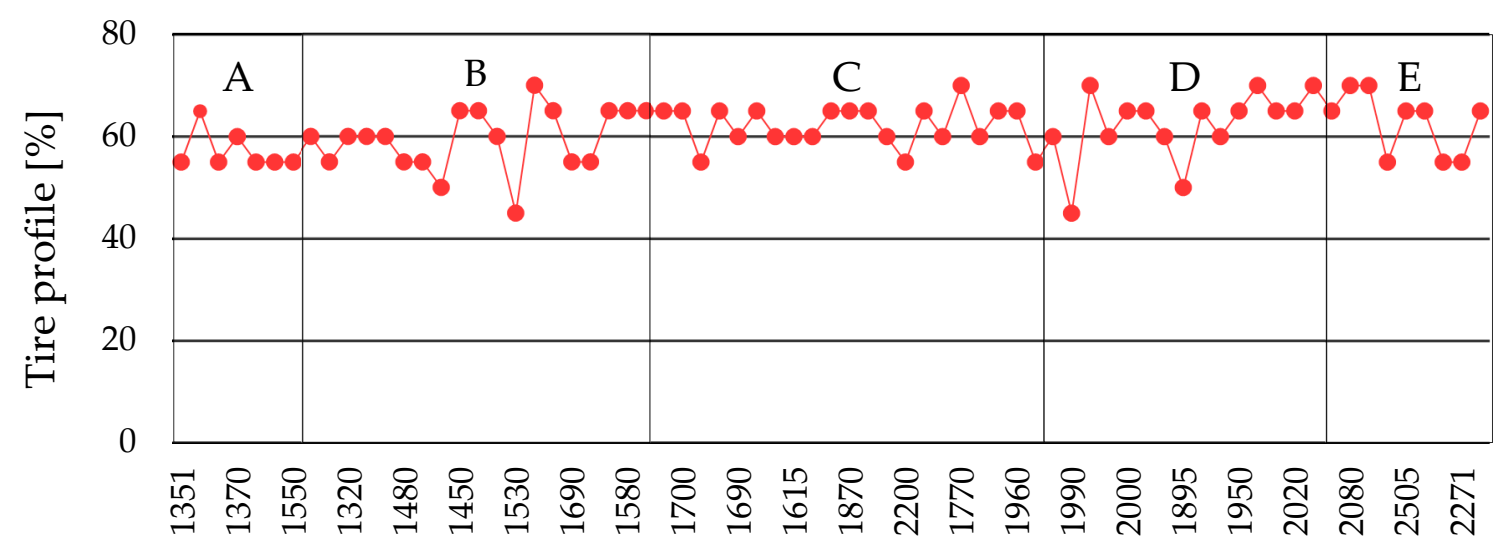

PGW of the vehicle $[\mathrm{kg}]$

Figure 2. Profiles of used tires depending on the permissible gross vehicle weight (segment $A$ to segment E); PGW - Permissible Gross vehicle Weight.

It should be emphasized that tire substitutes are available on the market. They are used to change some driving parameters, e.g., braking distance. Tires with a smaller diameter are usually much cheaper. The size of the replacements results from the comparison of the outer diameters of the reference tire and the one suggested as a replacement. If the difference is between $+1.5 \%$ and $-2 \%$, the tire can be used as a replacement for the original tire [80].

\subsection{Tire Size Depending on the Date of Manufacture of the Vehicle}

Because manufacturers offer different sizes of engines and different equipment for a given vehicle model, the average width and average tire profile for a given car model were calculated. The dependence of the tire width and its profile are represented respectively in Figures 3 and 4 . The newer the cars, the wider and lower the profile. As it results from literature studies, the reduction of the tire profile [index $H=$ height/width] allows the increase of the contact surface of the tread with the road and, consequently, a better adhesion of the vehicle is observed, especially on dry surfaces. 
The average width of the tyre in the function of the beginning of the production year

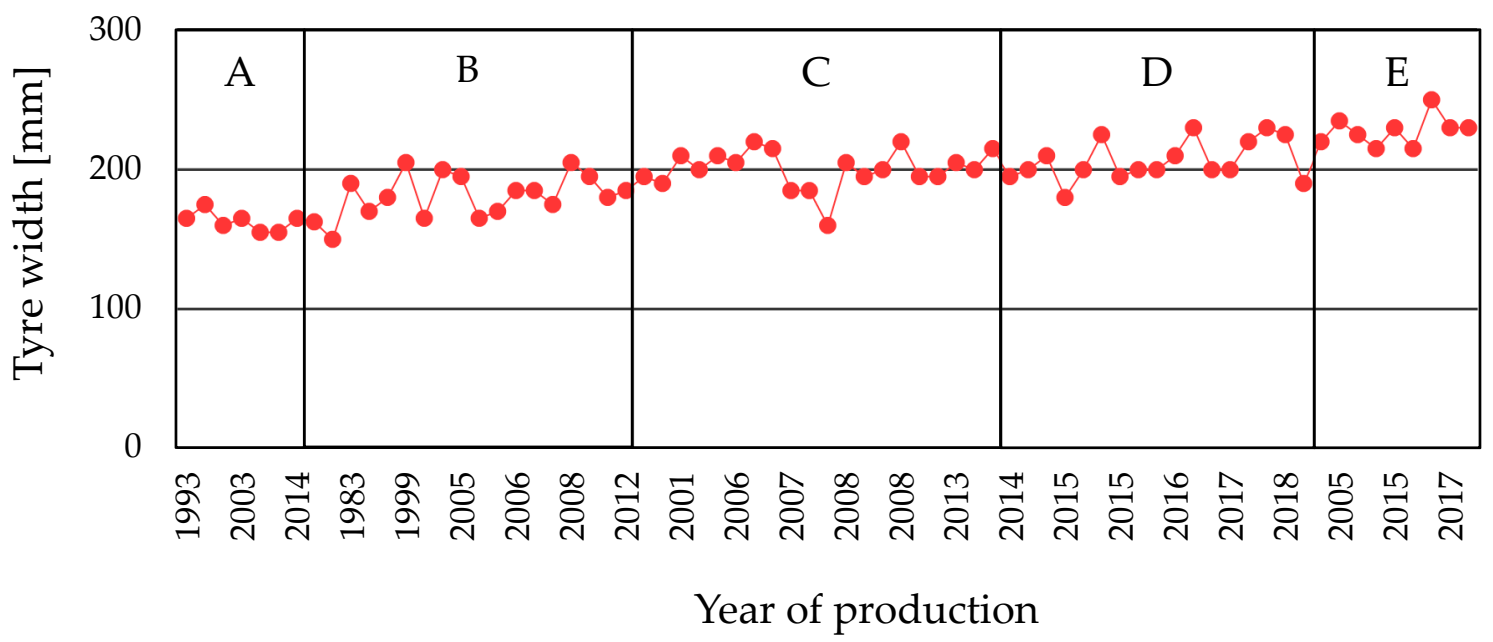

Figure 3. Profiles of used tires depending on the date of production of the vehicle (segment A to segment E).

Tire profile in the function of the beginning of the production

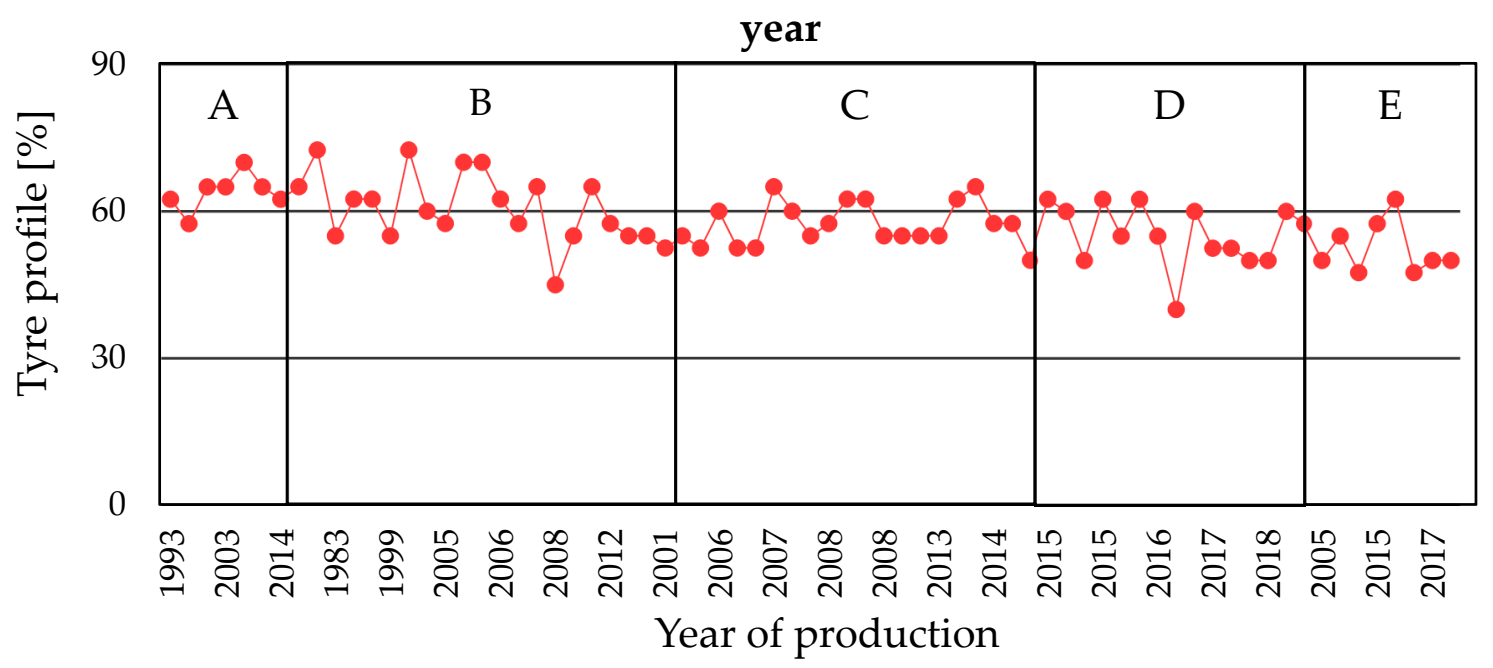

Figure 4. Profiles of tires applied depending on the date of production of the vehicle (segment A to segment E).

The subject literature on the impact of tires on road safety shows how much weight is attached to the tires of a vehicle. This results in the multiplicity and detail of regulations set for manufacturers regarding the approval of tires and for motorists in the field of proper tire use.

\subsection{Analysis of the Influence of Tires on the Braking Process During Control Ests on the VIS}

The main factor of the condition of the braking system, checked at a VIS, is the braking rate " $z$ ". Measurements are made on a roller stand (a quasi-static method) or on overlay plates (a dynamic method).

The braking performance is considered compliant with the requirements of the technical regulations if the braking rate measured (or calculated) based on the measurement of deceleration forces or braking delay is not less than specified in the technical specifications regulation. 
The braking rate is calculated according to the dependence:

$$
z=\frac{\sum T}{P} \cdot 100
$$

Where

$z$-braking rate (\%) for the type of brake tested;

$\Sigma T$-braking forces obtained from all wheels $(\mathrm{kN})$, respectively for service, emergency, or parking brake;

$P$-force of gravity (pressure) from the permissible total weight of the tested vehicle $(\mathrm{kN})$, assuming for the calculation: $1 \mathrm{kN}$ = gravity of $100 \mathrm{~kg}$ of mass.

The permissible gross vehicle weight is based on the data contained in the registration certificate, the nameplate, or other reliable technical data of the vehicle, or is calculated by adding the vehicle's own weight and the permissible load capacity of the vehicle; for lorries, the permissible load is the permissible pressure on the lorry's fifth wheel coupling. If the measured braking force of the service brake or the braking rate thus calculated does not reach the required value, calculate the maximum value of the braking force (or calculated braking effectiveness rate) by multiplying the measured braking forces of the individual wheels by the ratio of the maximum permissible force on the brake lever to the pressure exerted during the measurement or by the ratio of the calculated pressure in the braking system to the pressure in the brake cylinders measured during the measurement on this axis, according to the following dependency:

$$
\begin{gathered}
T_{\min }=P \cdot z_{\min } \\
T^{*}=\sum\left(T \cdot \frac{P_{d}}{P_{z}}\right)_{i} \\
z^{*}=\frac{T^{*}}{P} \cdot 100
\end{gathered}
$$

Where

$T_{\text {min }}$ - minimum required working brake force $(\mathrm{kN})$;

$P$-force of gravity (pressure) from the permissible total weight of the tested vehicle $(\mathrm{kN})$, assuming for the calculation: $1 \mathrm{kN}$ = gravity of $100 \mathrm{~kg}$ of mass (for articulated vehicles, it is allowed to accept for the calculations the permissible pressure of a given axis);

$z_{\text {min }}$-required breaking effectiveness rate (\%);

$T^{*}$ - calculated brake force of the service brake $(\mathrm{kN})$;

$z^{*}$-calculated breaking effectiveness rate $(\%)$

$T$-braking force obtained from all wheels of a given axle $(\mathrm{kN})$

I-the nest tested vehicle axis;

$P_{z}$-measured pressure on the brake pedal (lever) or measured pressure in sevomotors (daN or MPa);

$P_{d}$-permissible pressure on the brake pedal (lever) for a given vehicle or calculated pressure (lower regulated or specified by the vehicle manufacturer) of a pneumatic braking system (daN or MPa).

The calculated braking force or calculated braking effectiveness rate calculated in this way must be compared again with the value required for the type of vehicle. The permissible limit values of the " $Z$ " index depend on the type of vehicle, type approval, and the date of the first registration.

Laboratory tests were carried out on a measurement stand consisting of an APS-10 manometer with a $0.01 \mathrm{MPa}$ measuring scale developed by FOUS, by means of which the pressure state of inflating the tires is brought to nominal values recommended by the manufacturer of a given vehicle. Measurements of braking forces were carried out on the diagnostic line made by Ryme, intended for testing passenger cars, vans, and agricultural tractors with a maximum permissible weight of up 
to 3.5 tons. According to the manufacturer, the accuracy of the measurements indicated is $0.01 \mathrm{kN}$. The diagnostic line consists of:

- Weight measuring the axle of the vehicle (result calculated per $\mathrm{kg}$ );

- $\quad$ Two drive units that are made up of: A gear motor and a system of two rollers (welded steel drums) connected by a chain (Figure 5a,b);

- $\quad$ Aa system that measures braking forces using strain gauges.

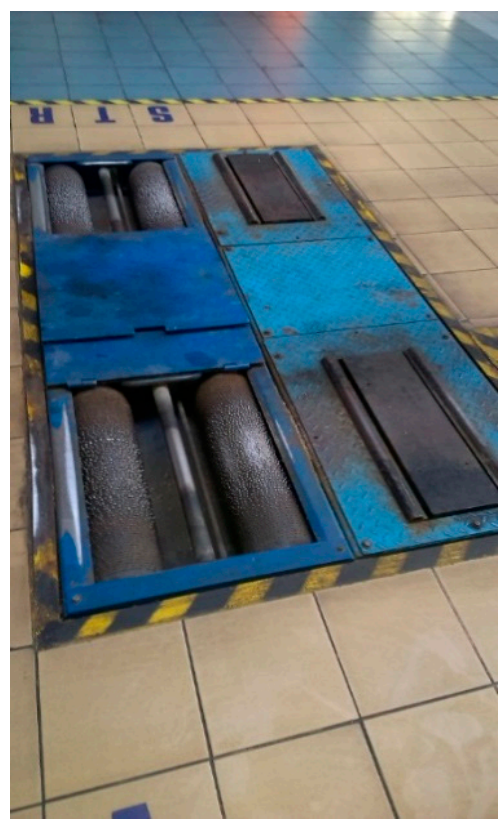

(a)

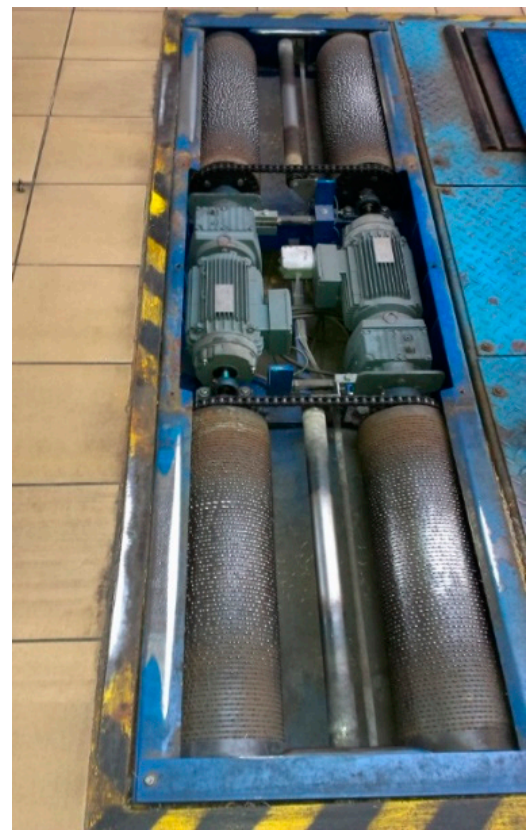

(b)

Figure 5. Diagnostic line: (a) Weight for measuring mass pressures of vehicle wheels; (b) drive rollers with visible gearmotors.

In addition, the station is equipped with a device measuring the pressure on the brake pedal with the transmitter (Figure 6a) and measuring rollers for measuring the rotational speed of the vehicle's wheels (Figure 6b).

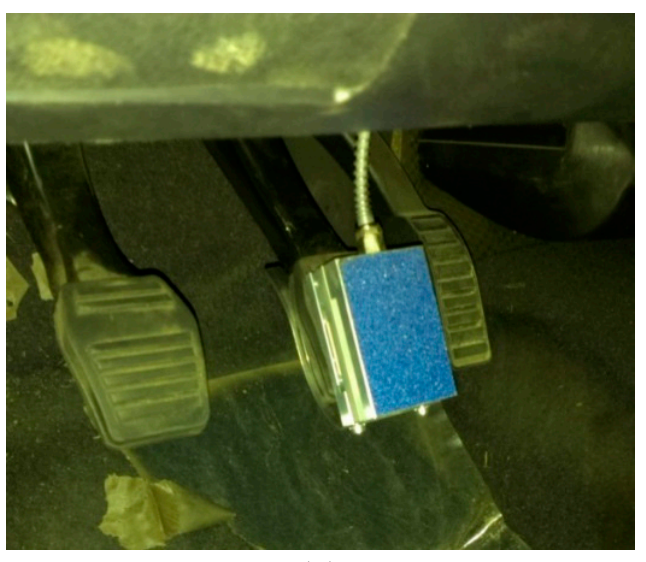

(a)

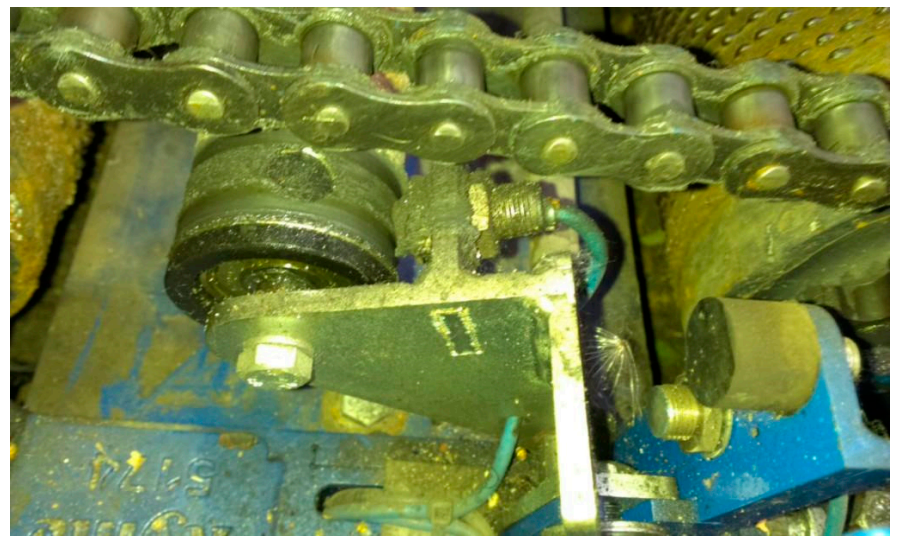

(b)

Figure 6. Additional station equipment: (a) Pedal force meter; (b) measuring roller and wheel rotational speed sensor.

The entire diagnostic line is controlled by the central unit and the measurement results are displayed on the screen monitor and optionally stored in the database and printed. 
The measurement of braking forces in a roller device is called the quasi-static method [81]. The rotational speed of the drive rollers and thus the circumferential speed of the road wheels during the test is very low and corresponds to a vehicle speed of approximately $5.5 \mathrm{~km} / \mathrm{h}$. The coefficient of adhesion of wheels to drive rollers established by the manufacturer of the "Ryme" diagnostic line is 0.9 for the dry state and 0.7 for the wet state [82]. The measurement is carried out in subsequent stages. First, the front axle of the vehicle is weighed, then the braking forces on the wheels of this axle are measured and stored. Then, the rear axle of the vehicle is weighed, and the braking forces of the rear wheels are measured. In both stages, the measurement of braking force ends when the rollers are stopped by the measuring system, which happens when the maximum slip equal to $35 \%$, programmed in the operating parameters of the line is reached, or when the maximum permissible pressure on the brake pedal, as defined by regulations, is reached.

Under the conditions of measurements on the VIS, vehicles are rarely tested at full load. Therefore, the wheels often stop (especially when measuring in "wet" conditions) before reaching the maximum prescribed forces on the brake pedal. It is caused by the achievement of the maximum 35\% slip value assumed in the measuring system. In order to determine the maximum braking force that can be achieved on a given vehicle in real conditions, a legally permissible extrapolation method is used. It assumes the proportionality of the braking force obtained on the wheels to the force exerted on the brake pedal. The braking performance coefficient is calculated according to the principle described above.

All measurements were made in "dry" conditions, i.e., the rollers and tires were free from impurities, and the ambient temperature was around $20^{\circ} \mathrm{C}$. The measurements were made by the same driver. Two passenger cars of the $C$ segment, the five-door lift back type, were used for the tests:

- $\quad$ Ford Escort-MKVII $1.616 \mathrm{~V}$, with a mileage of $200 \mathrm{~km}$,

- Opel Astra-G $1.416 \mathrm{~V}$, with a mileage of 165,000 km.

The braking systems of both vehicles were in perfect technical condition during the measurement. Both vehicles have hydraulic braking systems with power steering, equipped with ABS (Anti-lock Braking System). During the test series on the test bench, the braking forces of the front (drive) axle wheels were measured. The engines of both vehicles were running, and the clutch was not switched off. The vehicles were equipped with the following tires:

1. FORD ESCORT-GOODYEAR GT 175/70 R13 82T-with a tread depth: $6.45 \mathrm{~mm}$ in the right wheel (Figure $7 \mathrm{a}$ ) and $3.5 \mathrm{~mm}$ in the left wheel (Figure $7 \mathrm{~b}$ );

2. OPEL ASTRA-CONTINENTAL 185/65 R15 88T-with a tread depth of $7.93 \mathrm{~mm}$ in the right wheel (Figure $8 \mathrm{a}$ ) and $4.31 \mathrm{~mm}$ in the left wheel (Figure $8 \mathrm{~b}$ ).

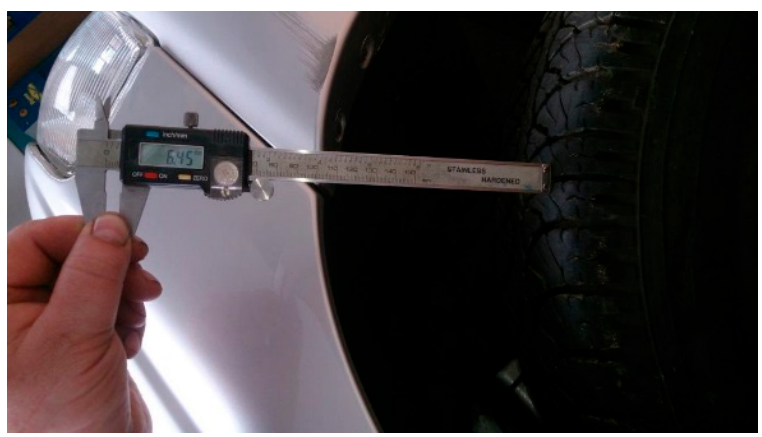

(a)

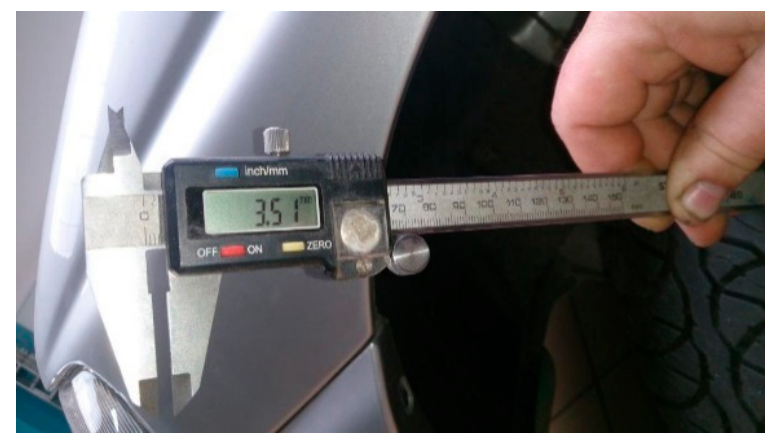

(b)

Figure 7. Tread depth measurement: (a) Opel Astra, right wheel; (b) Opel Astra, left wheel. 


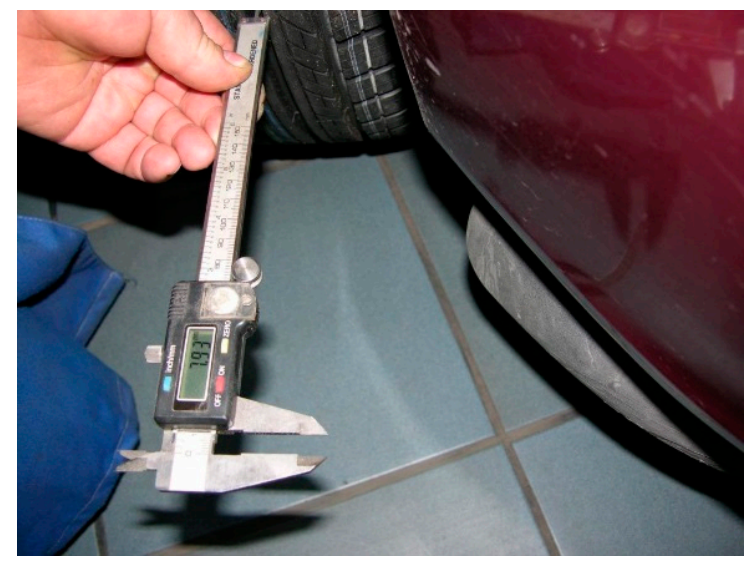

(a)

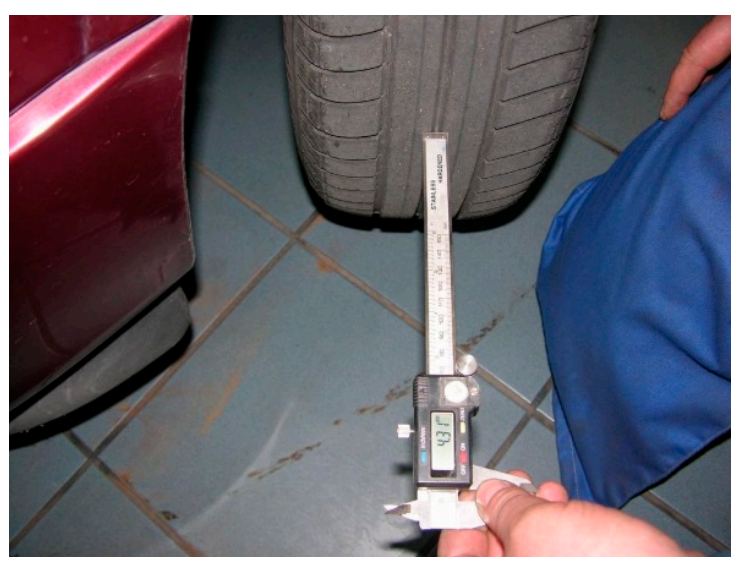

(b)

Figure 8. Tread depth measurement: (a) Opel Astra, right wheel; (b) Opel Astra, left wheel.

\section{Results}

\subsection{Measurements of the Weight of the Front Axle Wheels-0 Series}

The "Ryme" diagnostic line, in the part designed for determining the wheel pressures exerted on the road, which afterwards are used to determine the braking efficiency, gives the total mass resulting from the pressure of both wheels on one axle as the result of the measurement. In order to eliminate possible differences in measurements of braking forces, resulting from unequal calibration of both scales, an attempt was made to weigh the wheels of the front axle, left and right individually. These measurements are named in the description of the measuring cards as the series " 0 ".

Measurements of the front wheel axle mass (the so-called " 0 " series) were performed by approaching the diagnostic line with one wheel (left or right), in two directions: consistent with the direction of motion of the diagnostic line and in the opposite direction. The measurements showed a slight mass difference in favor of the left wheel. A possible cause might be the driver's own weight. In addition, the left scale indicates smaller masses of the same wheel as the right scale, which indicates small differences in scales calibration (Table 1).

Table 1. Weights measured on the scales of the diagnostic line $[\mathrm{kg}]$.

\begin{tabular}{ccc}
\hline Scale & Left Wheel & Right Wheel \\
\hline Left scale & 422 & 352 \\
Right scale & 429 & 373 \\
\hline
\end{tabular}

\subsection{Interval Measurements of Braking Forces-Series I}

Then, two series of interval measurements of braking forces were made. They are to determine the effect of time intervals between measurements on the reproducibility of the results of the measured braking forces. Before taking the measurements, the pressure in the tires was brought to $0.21 \mathrm{MPa}$, according to the manufacturer's recommendations. In the first series, 15 measurements were made, simultaneously for the left and right wheels. The measurements were carried out successively: Every 6, 4 , and $2 \mathrm{~min}$. In order to avoid additional heating up of the braking system by the cooling fan, the engine of the vehicle was switched off after each measurement. The results of the braking force measurements in the first series are presented in Table 2. As can be seen from the series of measurements carried out, a large dispersion of the obtained results can be seen $(8 \%)$, while no clear correlation is found between the time intervals between the measurements and the values of the obtained braking forces. It can be noticed that when using time intervals of $4 \mathrm{~min}$, the highest braking forces were obtained. 
Table 2. Braking forces at various time intervals.

\begin{tabular}{ccccccc}
\hline \multicolumn{7}{c}{ Left Wheel } \\
\hline $\begin{array}{c}\text { Measurement } \\
\text { Number }\end{array}$ & $\begin{array}{c}\text { Interval } \\
\mathbf{2} \text { min. }\end{array}$ & $\begin{array}{c}\text { Interval } \\
\mathbf{4} \text { min. }\end{array}$ & $\begin{array}{c}\text { Interval } \\
\mathbf{6} \text { min. }\end{array}$ & $\begin{array}{c}\text { Interval } \\
\mathbf{2} \text { min. }\end{array}$ & $\begin{array}{c}\text { Interval } \\
\mathbf{4} \text { min. }\end{array}$ & $\begin{array}{c}\text { Interval } \\
\mathbf{~ m i n .}\end{array}$ \\
\hline 1 & 2.16 & 2.11 & 2.29 & 2.04 & 2.03 & 2.15 \\
2 & 2.05 & 2.21 & 2.17 & 1.88 & 2.12 & 2.07 \\
3 & 2.24 & 2.24 & 2.25 & 2.11 & 2.18 & 2.18 \\
4 & 2.11 & 2.27 & 2.00 & 1.98 & 2.13 & 2.02 \\
5 & 2.07 & 2.23 & 2.21 & 1.95 & 2.17 & 2.12 \\
\hline $\begin{array}{c}\text { Average } \\
\text { value }\end{array}$ & $\mathbf{2 . 1 3}$ & $\mathbf{2 . 2 1}$ & $\mathbf{2 . 1 8}$ & $\mathbf{1 . 9 9}$ & $\mathbf{2 . 1 3}$ & $\mathbf{2 . 1 1}$ \\
\hline $\begin{array}{c}\text { Standard } \\
\text { deviation }\end{array}$ & $\mathbf{0 . 0 8}$ & $\mathbf{0 . 0 6}$ & $\mathbf{0 . 1 1}$ & $\mathbf{0 . 0 9}$ & $\mathbf{0 . 0 6}$ & $\mathbf{0 . 0 6}$ \\
\hline
\end{tabular}

\subsection{Measurements of Braking Forces Depending on the Pressure on the Brake Pedal—Series II}

In the second series of measurements, an attempt was made to determine the dependence of the braking force obtained on the wheels from the pressure on the brake pedal. Before the measurements, the tire pressure was adjusted to $0.21 \mathrm{MPa}$ (according to the manufacturer's recommendations). In this series, 15 measurements were also made, five for each pedal force: $100 \mathrm{~N}, 110 \mathrm{~N}$, and $120 \mathrm{~N}$. A 4-min time interval between measurements was used. The values of obtained forces on wheels are shown in Table 3.

Table 3. Values of forces on the wheels of the tested vehicle.

\begin{tabular}{ccccccc}
\hline & \multicolumn{3}{c}{ Left Wheel } & \multicolumn{3}{c}{ Right Wheel } \\
\hline & & & \multicolumn{2}{c}{ Pedal Force [N] } \\
\hline Measurement Number & $\mathbf{1 0 0}$ & $\mathbf{1 1 0}$ & $\mathbf{1 2 0}$ & $\mathbf{1 0 0}$ & $\mathbf{1 1 0}$ & $\mathbf{1 2 0}$ \\
\hline 1 & 1.04 & 1.39 & 1.65 & 1.06 & 1.41 & 1.67 \\
2 & 1.14 & 1.34 & 1.57 & 1.16 & 1.33 & 1.60 \\
3 & 1.14 & 1.48 & 1.65 & 1.16 & 1.48 & 1.71 \\
4 & 1.10 & 1.36 & 1.74 & 1.10 & 1.45 & 1.76 \\
5 & 1.16 & 1.34 & 1.68 & 1.16 & 1.40 & 1.73 \\
\hline Average force on the wheels [kN] & $\mathbf{1 . 1 2}$ & $\mathbf{1 . 3 8}$ & $\mathbf{1 . 6 6}$ & $\mathbf{1 . 1 3}$ & $\mathbf{1 . 4 1}$ & $\mathbf{1 . 6 9}$ \\
\hline
\end{tabular}

Despite the noticeable dispersion of the results, it can be concluded that the braking force on the wheels increases in proportion to the increase in force applied to the brake pedal. This trend is the same for both wheels of the front axle.

\subsection{Measurements of Braking Forces at Varying Tire Inflation Pressures-Series III, IV, V, VI}

In the next part of the research, the braking forces on the wheels of the front axle of vehicles were analyzed, in two series each (with and without a payload). Measurements were made at varying inflation pressure values of tires: From $0.15 \mathrm{MPa}$ to $0.31 \mathrm{MPa}$. In both vehicles, on the left and right sides, tires with very different wear were used. The vehicles were loaded with steel weights, spread evenly on the floor of the vehicle, imitating the load of passengers. The mass of the loads was measured by subtracting the weight of unloaded vehicles from the total weight of the loaded vehicles. Due to the fact that the rollers stopped at different values of the pressure on the brake pedal, the arithmetic mean of the force from a given series of measurements was used to create diagrams of the dependence of braking force in the function of the tire inflation pressure. The measured braking forces were calculated 
as ratios of measured pedal force to the average force of the whole series. This allowed to overcome the dispersion of the measurement due to the rollers stopping at different pressures on the brake pedal.

Tables 4-7 summarize the results of measurements of braking forces in the front axle wheels for both vehicles at different payloads. Based on the measurement results obtained, diagrams of braking forces as a function of tire inflation pressure were drawn (Figures 9-12).

Table 4. Braking forces FORD ESCORT without additional load-III series. Load: Driver; vehicle weight: $1265 \mathrm{~kg}$; front axle weight: $763 \mathrm{~kg}$.

\begin{tabular}{|c|c|c|c|c|c|c|}
\hline $\begin{array}{l}\text { Measurement } \\
\text { Number }\end{array}$ & $\begin{array}{l}\text { Pumping } \\
\text { Pressure }\end{array}$ & $\begin{array}{l}\text { Force on the } \\
\text { Brake Pedal }\end{array}$ & $\begin{array}{c}\text { Braking } \\
\text { Force Left } \\
\text { Wheel }\end{array}$ & $\begin{array}{l}\text { Braking Force Left } \\
\text { Wheel Converted } \\
\text { to the Pressure } \\
145 \mathrm{~N} \text { on the Pedal }\end{array}$ & $\begin{array}{l}\text { Braking } \\
\text { Force Right } \\
\text { Wheel }\end{array}$ & $\begin{array}{l}\text { Braking Force } \\
\text { Right Wheel } \\
\text { Converted to the } \\
\text { Pressure } 145 \mathrm{~N} \text { on } \\
\text { the Pedal }\end{array}$ \\
\hline & [MPa] & {$[\mathrm{N}]$} & {$[\mathrm{kN}]$} & {$[\mathrm{kN}]$} & {$[\mathrm{kN}]$} & {$[\mathrm{kN}]$} \\
\hline 1 & 0.14 & 148 & 2.02 & 1.98 & 2.10 & 2.06 \\
\hline 2 & 0.14 & 149 & 1.86 & 1.81 & 1.95 & 1.90 \\
\hline 3 & 0.15 & 147 & 2.11 & 2.08 & 2.21 & 2.18 \\
\hline 4 & 0.15 & 146 & 2.06 & 2.05 & 1.98 & 1.97 \\
\hline 5 & 0.16 & 152 & 2.23 & 2.13 & 2.28 & 2.18 \\
\hline 6 & 0.16 & 154 & 2.33 & 2.19 & 2.19 & 2.06 \\
\hline 7 & 0.17 & 148 & 2.17 & 2.13 & 2.05 & 2.01 \\
\hline 8 & 0.17 & 154 & 2.39 & 2.25 & 2.20 & 2.07 \\
\hline 9 & 0.18 & 151 & 2.21 & 2.12 & 2.17 & 2.08 \\
\hline 10 & 0.18 & 146 & 2.12 & 2.11 & 2.06 & 2.05 \\
\hline 11 & 0.19 & 126 & 2.01 & 2.31 & 2.06 & 2.37 \\
\hline 12 & 0.19 & 131 & 2.06 & 2.28 & 2.07 & 2.29 \\
\hline 13 & 0.20 & 129 & 2.01 & 2.26 & 2.05 & 2.30 \\
\hline 14 & 0.20 & 133 & 2.12 & 2.31 & 2.13 & 2.32 \\
\hline 15 & 0.21 & 135 & 2.07 & 2.22 & 2.09 & 2.24 \\
\hline 16 & 0.21 & 146 & 2.14 & 2.13 & 2.16 & 2.15 \\
\hline 17 & 0.22 & 143 & 2.12 & 2.15 & 2.12 & 2.15 \\
\hline 18 & 0.22 & 151 & 2.12 & 2.04 & 2.16 & 2.07 \\
\hline 19 & 0.23 & 146 & 2.14 & 2.13 & 2.15 & 2.14 \\
\hline 20 & 0.23 & 151 & 2.23 & 2.14 & 2.19 & 2.10 \\
\hline 21 & 0.24 & 148 & 2.12 & 2.08 & 2.14 & 2.10 \\
\hline 22 & 0.24 & 149 & 2.10 & 2.04 & 2.13 & 2.07 \\
\hline 23 & 0.25 & 140 & 2.02 & 2.09 & 2.04 & 2.11 \\
\hline 24 & 0.25 & 146 & 2.14 & 2.13 & 2.14 & 2.13 \\
\hline 25 & 0.26 & 143 & 2.11 & 2.14 & 2.12 & 2.15 \\
\hline 26 & 0.26 & 148 & 2.14 & 2.10 & 2.15 & 2.11 \\
\hline 27 & 0.27 & 146 & 2.10 & 2.09 & 2.12 & 2.11 \\
\hline 28 & 0.27 & 151 & 2.23 & 2.14 & 2.21 & 2.12 \\
\hline 29 & 0.28 & 148 & 2.14 & 2.10 & 2.17 & 2.13 \\
\hline 30 & 0.28 & 140 & 2.11 & 2.19 & 2.10 & 2.18 \\
\hline 31 & 0.29 & 140 & 2.09 & 2.16 & 2.11 & 2.19 \\
\hline 32 & 0.29 & 141 & 2.11 & 2.17 & 2.13 & 2.19 \\
\hline 33 & 0.30 & 143 & 2.16 & 2.19 & 2.12 & 2.15 \\
\hline \multirow[t]{2}{*}{34} & 0.30 & 151 & 2.21 & 2.12 & 2.21 & 2.12 \\
\hline & Average & 145 & & 2.13 & & 2.13 \\
\hline
\end{tabular}

Table 5. Brake force of FORD ESCORT loaded with an additional weight of $307 \mathrm{~kg}$-Series IV. Load: Driver +307 kg; vehicle weight: $1572 \mathrm{~kg}$; front axle weight: $924 \mathrm{~kg}$.

\begin{tabular}{ccccccc}
\hline $\begin{array}{c}\text { Measurement } \\
\text { Number }\end{array}$ & $\begin{array}{c}\text { Pumping } \\
\text { Pressure }\end{array}$ & $\begin{array}{c}\text { Force on the } \\
\text { Brake Pedal }\end{array}$ & $\begin{array}{c}\text { Braking } \\
\text { Force Left } \\
\text { Wheel }\end{array}$ & $\begin{array}{c}\text { Braking Force Left } \\
\text { Wheel Converted } \\
\text { to the Pressure } \\
\mathbf{1 6 2} \mathbf{N} \text { on the Pedal }\end{array}$ & $\begin{array}{c}\text { Braking } \\
\text { Force Right } \\
\text { Wheel }\end{array}$ & $\begin{array}{c}\text { Braking Force } \\
\text { Right Wheel } \\
\text { Converted to the } \\
\text { Pressure 162 N on } \\
\text { the Pedal }\end{array}$ \\
\hline 1 & {$[\mathrm{MPa}]$} & {$[\mathbf{N}]$} & {$[\mathbf{k N}]$} & {$[\mathbf{k N}]$} & {$[\mathbf{k N}]$} & {$[\mathbf{k N ]}$} \\
\hline 3 & 0.15 & 166 & 2.55 & 2.49 & 2.50 & 2.44 \\
3 & 0.15 & 166 & 2.75 & 2.68 & 2.60 & 2.54 \\
\hline
\end{tabular}


Table 5. Cont.

\begin{tabular}{|c|c|c|c|c|c|c|}
\hline $\begin{array}{l}\text { Measurement } \\
\text { Number }\end{array}$ & $\begin{array}{l}\text { Pumping } \\
\text { Pressure }\end{array}$ & $\begin{array}{l}\text { Force on the } \\
\text { Brake Pedal }\end{array}$ & $\begin{array}{l}\text { Braking } \\
\text { Force Left } \\
\text { Wheel }\end{array}$ & $\begin{array}{l}\text { Braking Force Left } \\
\text { Wheel Converted } \\
\text { to the Pressure } \\
162 \mathrm{~N} \text { on the Pedal }\end{array}$ & $\begin{array}{l}\text { Braking } \\
\text { Force Right } \\
\text { Wheel }\end{array}$ & $\begin{array}{l}\text { Braking Force } \\
\text { Right Wheel } \\
\text { Converted to the } \\
\text { Pressure } 162 \mathrm{~N} \text { on } \\
\text { the Pedal }\end{array}$ \\
\hline & [MPa] & {$[N]$} & {$[\mathrm{kN}]$} & {$[\mathrm{kN}]$} & {$[\mathrm{kN}]$} & {$[\mathrm{kN}]$} \\
\hline 4 & 0.16 & 168 & 2.81 & 2.71 & 2.72 & 2.62 \\
\hline 5 & 0.17 & 157 & 2.55 & 2.63 & 2.60 & 2.68 \\
\hline 6 & 0.17 & 174 & 2.84 & 2.64 & 2.77 & 2.58 \\
\hline 7 & 0.18 & 158 & 2.52 & 2.58 & 2.61 & 2.68 \\
\hline 8 & 0.18 & 165 & 2.74 & 2.69 & 2.59 & 2.54 \\
\hline 9 & 0.19 & 154 & 2.37 & 2.49 & 2.47 & 2.60 \\
\hline 10 & 0.19 & 154 & 2.48 & 2.61 & 2.51 & 2.64 \\
\hline 11 & 0.20 & 160 & 2.58 & 2.61 & 2.63 & 2.66 \\
\hline 12 & 0.20 & 166 & 2.63 & 2.57 & 2.76 & 2.69 \\
\hline 13 & 0.21 & 151 & 2.40 & 2.57 & 2.48 & 2.66 \\
\hline 14 & 0.21 & 154 & 2.48 & 2.61 & 2.55 & 2.68 \\
\hline 15 & 0.22 & 154 & 2.28 & 2.40 & 2.39 & 2.51 \\
\hline 16 & 0.22 & 154 & 2.33 & 2.45 & 2.44 & 2.57 \\
\hline 17 & 0.23 & 171 & 2.59 & 2.45 & 2.60 & 2.46 \\
\hline 18 & 0.23 & 163 & 2.43 & 2.42 & 2.40 & 2.39 \\
\hline 19 & 0.24 & 169 & 2.67 & 2.56 & 2.57 & 2.46 \\
\hline 20 & 0.24 & 165 & 2.54 & 2.49 & 2.48 & 2.43 \\
\hline 21 & 0.25 & 171 & 2.62 & 2.48 & 2.48 & 2.35 \\
\hline 22 & 0.25 & 160 & 2.53 & 2.56 & 2.62 & 2.65 \\
\hline 23 & 0.26 & 166 & 2.60 & 2.54 & 2.52 & 2.46 \\
\hline 24 & 0.26 & 160 & 2.43 & 2.46 & 2.49 & 2.52 \\
\hline 25 & 0.27 & 169 & 2.53 & 2.43 & 2.47 & 2.37 \\
\hline 26 & 0.27 & 161 & 2.58 & 2.60 & 2.63 & 2.65 \\
\hline 27 & 0.28 & 168 & 2.57 & 2.48 & 2.66 & 2.57 \\
\hline 28 & 0.28 & 158 & 2.46 & 2.52 & 2.56 & 2.62 \\
\hline 29 & 0.29 & 157 & 2.37 & 2.45 & 2.51 & 2.59 \\
\hline 30 & 0.29 & 160 & 2.51 & 2.54 & 2.56 & 2.59 \\
\hline 31 & 0.30 & 160 & 2.49 & 2.52 & 2.61 & 2.64 \\
\hline 32 & 0.30 & 166 & 2.58 & 2.52 & 2.63 & 2.57 \\
\hline 33 & 0.31 & 158 & 2.49 & 2.55 & 2.29 & 2.35 \\
\hline \multirow[t]{2}{*}{34} & 0.31 & 165 & 2.66 & 2.61 & 2.65 & 2.60 \\
\hline & Average & 162 & & 2.54 & & 2.55 \\
\hline
\end{tabular}

Table 6. Braking forces OPEL ASTRA without additional load—series V. Load: Steering; vehicle weight: $1231 \mathrm{~kg}$; front axle weight: $761 \mathrm{~kg}$.

\begin{tabular}{|c|c|c|c|c|c|c|}
\hline $\begin{array}{l}\text { Measurement } \\
\text { Number }\end{array}$ & $\begin{array}{l}\text { Pumping } \\
\text { Pressure }\end{array}$ & $\begin{array}{l}\text { Force on the } \\
\text { Brake Pedal }\end{array}$ & $\begin{array}{c}\text { Braking } \\
\text { Force Left } \\
\text { Wheel }\end{array}$ & $\begin{array}{l}\text { Braking Force Left } \\
\text { Wheel Converted } \\
\text { to the Pressure } \\
140 \mathrm{~N} \text { on the Pedal }\end{array}$ & $\begin{array}{c}\text { Braking } \\
\text { Force Right } \\
\text { Wheel }\end{array}$ & $\begin{array}{c}\text { Braking Force } \\
\text { Right Wheel } \\
\text { Converted to the } \\
\text { Pressure } 140 \mathrm{~N} \text { on } \\
\text { the Pedal }\end{array}$ \\
\hline & [MPa] & {$[\mathbf{N}]$} & {$[\mathbf{k N}]$} & {$[\mathrm{kN}]$} & {$[\mathbf{k N}]$} & {$[\mathbf{k N}]$} \\
\hline 1 & 0.15 & 133 & 2.06 & 2.17 & 1.95 & 2.05 \\
\hline 2 & 0.15 & 136 & 1.89 & 1.95 & 1.83 & 1.88 \\
\hline 3 & 0.16 & 139 & 1.80 & 1.81 & 1.91 & 1.92 \\
\hline 4 & 0.16 & 140 & 1.94 & 1.94 & 1.94 & 1.94 \\
\hline 5 & 0.17 & 138 & 1.99 & 2.02 & 1.94 & 1.97 \\
\hline 6 & 0.17 & 131 & 1.79 & 1.91 & 1.84 & 1.97 \\
\hline 7 & 0.18 & 122 & 1.85 & 2.12 & 1.93 & 2.21 \\
\hline 8 & 0.18 & 136 & 1.97 & 2.03 & 1.98 & 2.04 \\
\hline 9 & 0.19 & 136 & 1.81 & 1.86 & 1.88 & 1.94 \\
\hline 10 & 0.19 & 137 & 1.89 & 1.93 & 1.83 & 1.87 \\
\hline 11 & 0.20 & 145 & 2.05 & 1.98 & 2.01 & 1.94 \\
\hline 12 & 0.20 & 135 & 1.85 & 1.92 & 1.88 & 1.95 \\
\hline 13 & 0.21 & 139 & 1.95 & 1.96 & 2.00 & 2.01 \\
\hline 14 & 0.21 & 152 & 2.10 & 1.93 & 2.02 & 1.86 \\
\hline 15 & 0.22 & 145 & 2.08 & 2.01 & 2.06 & 1.99 \\
\hline
\end{tabular}


Table 6. Cont.

\begin{tabular}{ccccccc}
\hline $\begin{array}{c}\text { Measurement } \\
\text { Number }\end{array}$ & $\begin{array}{c}\text { Pumping } \\
\text { Pressure }\end{array}$ & $\begin{array}{c}\text { Force on the } \\
\text { Brake Pedal }\end{array}$ & $\begin{array}{c}\text { Braking } \\
\text { Force Left } \\
\text { Wheel }\end{array}$ & $\begin{array}{c}\text { Braking Force Left } \\
\text { Wheel Converted } \\
\text { to the Pressure } \\
\text { 140 N on the Pedal }\end{array}$ & $\begin{array}{c}\text { Force Right } \\
\text { Wheel }\end{array}$ & $\begin{array}{c}\text { Braking Force } \\
\text { Right Wheel } \\
\text { Converted to the } \\
\text { Pressure 140 N on } \\
\text { the Pedal }\end{array}$ \\
\hline [MPa] & [N] & {$[\mathbf{k N}]$} & [kN] & {$[\mathbf{k N}]$} & [kN] \\
\hline 16 & 0.22 & 137 & 2.04 & 2.08 & 2.03 & 2.07 \\
17 & 0.23 & 146 & 2.18 & 2.09 & 2.23 & 2.14 \\
18 & 0.23 & 140 & 2.07 & 2.07 & 2.00 & 2.00 \\
19 & 0.24 & 145 & 2.00 & 1.93 & 2.03 & 1.96 \\
20 & 0.24 & 139 & 2.04 & 2.05 & 1.99 & 2.00 \\
21 & 0.25 & 139 & 2.03 & 2.04 & 2.09 & 2.11 \\
22 & 0.25 & 137 & 2.19 & 2.24 & 2.10 & 2.15 \\
23 & 0.26 & 146 & 2.21 & 2.12 & 2.04 & 2.13 \\
24 & 0.26 & 139 & 2.09 & 2.11 & 2.17 & 2.17 \\
25 & 0.27 & 140 & 2.09 & 2.09 & 2.21 & 2.18 \\
26 & 0.27 & 142 & 2.13 & 2.10 & 2.17 & 2.04 \\
27 & 0.28 & 149 & 2.19 & 2.06 & 2.16 & 2.11 \\
28 & 0.28 & 143 & 2.10 & 2.06 & 2.02 & 1.94 \\
29 & 0.29 & 146 & 2.07 & 1.98 & 2.15 & 2.12 \\
30 & 0.29 & 142 & 2.08 & 2.05 & 2.13 & 2.09 \\
31 & 0.30 & 143 & 2.14 & 2.10 & 2.07 & 2.03 \\
32 & 0.30 & 143 & 2.09 & 2.05 & 2.12 & 2.05 \\
33 & 0.31 & 143 & 2.01 & 1.97 & & $\mathbf{2 . 0 3}$ \\
\hline 34 & 0.31 & 145 & 2.05 & 1.98 & & \\
\hline
\end{tabular}

Table 7. Braking forces OPEL ASTRA loaded with an additional weight of $298 \mathrm{~kg}$-series VI. Load:

Driver +298 kg; vehicle weight: $1529 \mathrm{~kg}$; front axle weight: $884 \mathrm{~kg}$.

\begin{tabular}{|c|c|c|c|c|c|c|}
\hline $\begin{array}{l}\text { Measurement } \\
\text { Number }\end{array}$ & $\begin{array}{l}\text { Pumping } \\
\text { Pressure }\end{array}$ & $\begin{array}{l}\text { Force on the } \\
\text { Brake Pedal }\end{array}$ & $\begin{array}{l}\text { Braking } \\
\text { Force Left } \\
\text { Wheel }\end{array}$ & $\begin{array}{l}\text { Braking Force Left } \\
\text { Wheel Converted } \\
\text { to the Pressure } \\
172 \text { N on the Pedal }\end{array}$ & $\begin{array}{c}\text { Braking } \\
\text { Force Right } \\
\text { Wheel }\end{array}$ & $\begin{array}{l}\text { Braking Force } \\
\text { Right Wheel } \\
\text { Converted to the } \\
\text { Pressure } 172 \mathrm{~N} \text { on } \\
\text { the Pedal }\end{array}$ \\
\hline & [MPa] & {$[\mathrm{N}]$} & {$[\mathrm{kN}]$} & {$[\mathrm{kN}]$} & {$[\mathrm{kN}]$} & {$[\mathrm{kN}]$} \\
\hline 1 & 0.15 & 170 & 2.55 & 2.58 & 2.71 & 2.74 \\
\hline 2 & 0.15 & 171 & 2.57 & 2.59 & 2.72 & 2.74 \\
\hline 3 & 0.16 & 175 & 2.57 & 2.53 & 2.69 & 2.64 \\
\hline 4 & 0.16 & & & & & \\
\hline 5 & 0.17 & 161 & 2.16 & 2.31 & 2.25 & 2.40 \\
\hline 6 & 0.17 & 177 & 2.57 & 2.50 & 2.68 & 2.60 \\
\hline 7 & 0.18 & 166 & 2.41 & 2.50 & 2.55 & 2.64 \\
\hline 8 & 0.18 & 171 & 2.31 & 2.32 & 2.43 & 2.44 \\
\hline 9 & 0.19 & & & & & \\
\hline 10 & 0.19 & 168 & 2.43 & 2.49 & 2.58 & 2.64 \\
\hline 11 & 0.20 & 171 & 2.41 & 2.42 & 2.53 & 2.54 \\
\hline 12 & 0.20 & & & & & \\
\hline 13 & 0.21 & 170 & 2.46 & 2.49 & 2.62 & 2.65 \\
\hline 14 & 0.21 & 175 & 2.56 & 2.52 & 2.70 & 2.65 \\
\hline 15 & 0.22 & 173 & 2.50 & 2.49 & 2.67 & 2.65 \\
\hline 16 & 0.22 & 177 & 2.67 & 2.59 & 2.78 & 2.70 \\
\hline 17 & 0.23 & 175 & 2.60 & 2.56 & 2.72 & 2.67 \\
\hline 18 & 0.23 & 174 & 2.48 & 2.45 & 2.59 & 2.56 \\
\hline 19 & 0.24 & 171 & 2.45 & 2.46 & 2.57 & 2.59 \\
\hline 20 & 0.24 & 178 & 2.70 & 2.61 & 2.83 & 2.73 \\
\hline 21 & 0.25 & 178 & 2.59 & 2.50 & 2.72 & 2.63 \\
\hline 22 & 0.25 & 166 & 2.38 & 2.47 & 2.48 & 2.57 \\
\hline 23 & 0.26 & 174 & 2.58 & 2.55 & 2.69 & 2.66 \\
\hline 24 & 0.26 & 177 & 2.42 & 2.35 & 2.54 & 2.47 \\
\hline 25 & 0.27 & 171 & 2.47 & 2.48 & 2.59 & 2.61 \\
\hline
\end{tabular}


Table 7. Cont.

\begin{tabular}{|c|c|c|c|c|c|c|}
\hline $\begin{array}{l}\text { Measurement } \\
\text { Number }\end{array}$ & $\begin{array}{l}\text { Pumping } \\
\text { Pressure }\end{array}$ & $\begin{array}{l}\text { Force on the } \\
\text { Brake Pedal }\end{array}$ & $\begin{array}{c}\text { Braking } \\
\text { Force Left } \\
\text { Wheel }\end{array}$ & $\begin{array}{l}\text { Braking Force Left } \\
\text { Wheel Converted } \\
\text { to the Pressure } \\
172 \text { N on the Pedal }\end{array}$ & $\begin{array}{c}\text { Braking } \\
\text { Force Right } \\
\text { Wheel }\end{array}$ & $\begin{array}{c}\text { Braking Force } \\
\text { Right Wheel } \\
\text { Converted to the } \\
\text { Pressure } 172 \mathrm{~N} \text { on } \\
\text { the Pedal }\end{array}$ \\
\hline & [MPa] & [N] & {$[\mathrm{kN}]$} & {$[\mathrm{kN}]$} & {$[\mathrm{kN}]$} & {$[\mathrm{kN}]$} \\
\hline 26 & 0.27 & 183 & 2.58 & 2.42 & 2.70 & 2.54 \\
\hline 27 & 0.28 & 175 & 2.67 & 2.62 & 2.80 & 2.75 \\
\hline 28 & 0.28 & 177 & 2.49 & 2.42 & 2.54 & 2.47 \\
\hline 29 & 0.29 & 169 & 2.47 & 2.51 & 2.59 & 2.64 \\
\hline 30 & 0.29 & 175 & 2.57 & 2.53 & 2.67 & 2.62 \\
\hline 31 & 0.30 & 166 & 2.58 & 2.67 & 2.65 & 2.75 \\
\hline 32 & 0.30 & 161 & 2.26 & 2.41 & 2.37 & 2.53 \\
\hline 33 & 0.31 & 168 & 2.43 & 2.49 & 2.51 & 2.57 \\
\hline \multirow[t]{2}{*}{34} & 0.31 & 165 & 2.55 & 2.66 & 2.31 & 2.41 \\
\hline & Average & 172 & & 2.50 & & 2.61 \\
\hline
\end{tabular}

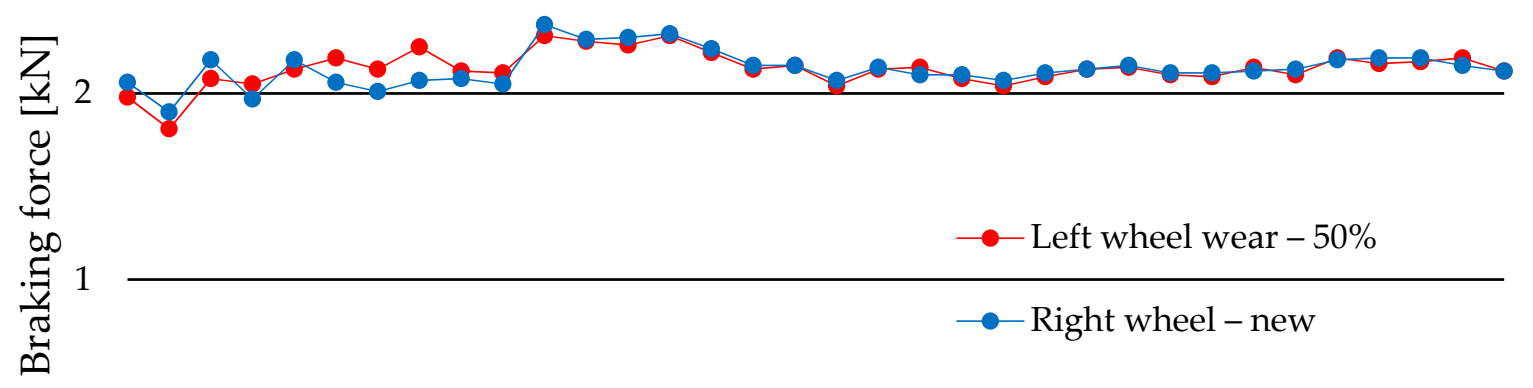

0 サ. Inflation pressure $[\mathrm{MPa}]$

Figure 9. Breaking force in the function of tire inflation pressure-FORT ESCORT, unloaded.

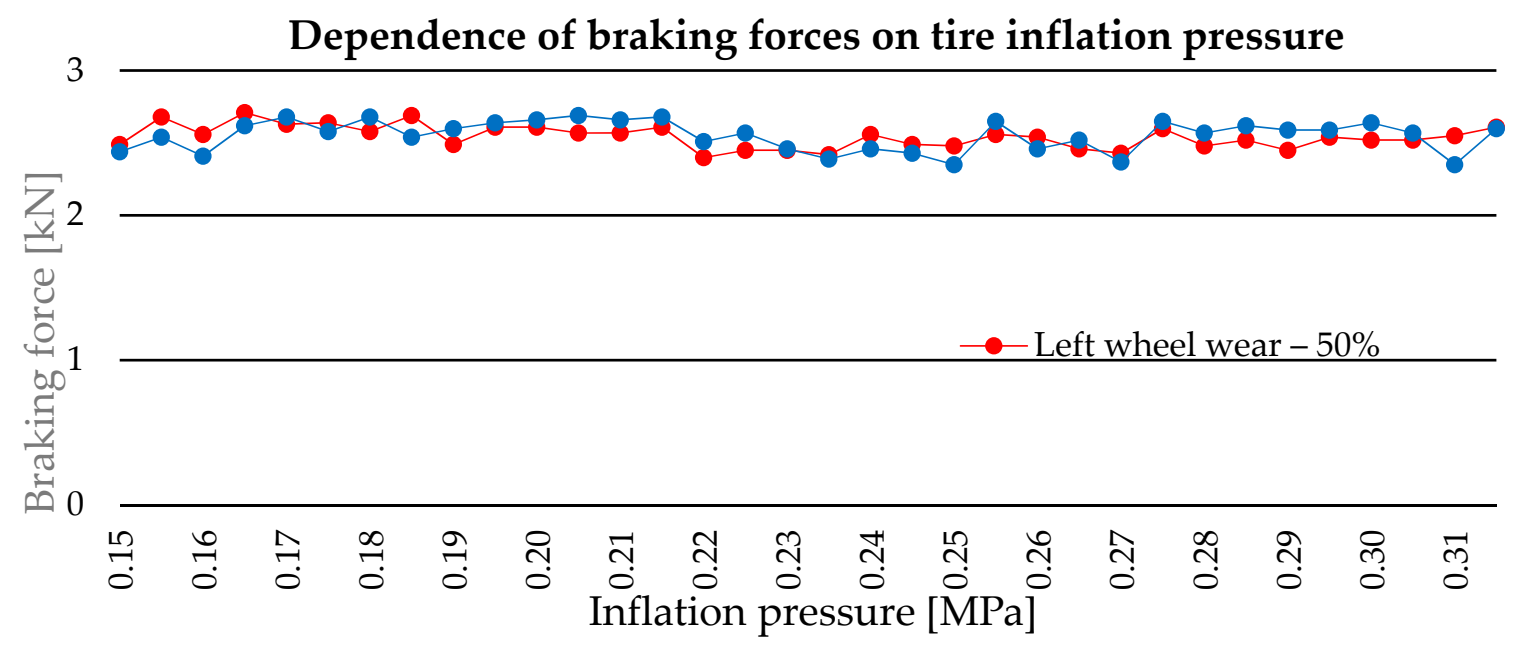

Figure 10. Breaking force in the function of tire inflation pressure-FORT ESCORT, loaded. 
Dependence of braking forces on tire inflation pressure

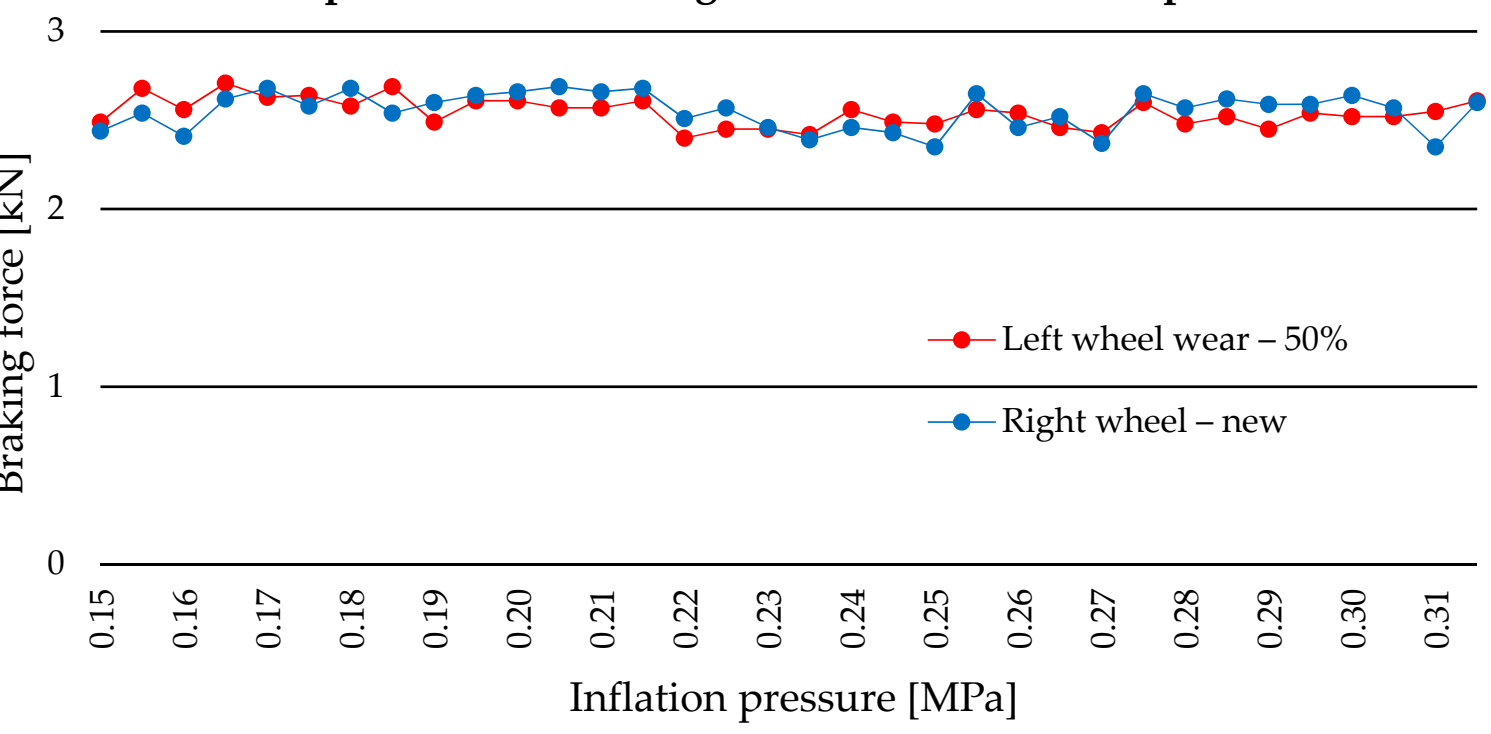

Figure 11. Breaking force in the function of tire inflation pressure-OPEL ASTRA, unloaded.

\section{Dependence of braking forces on tire inflation pressure}

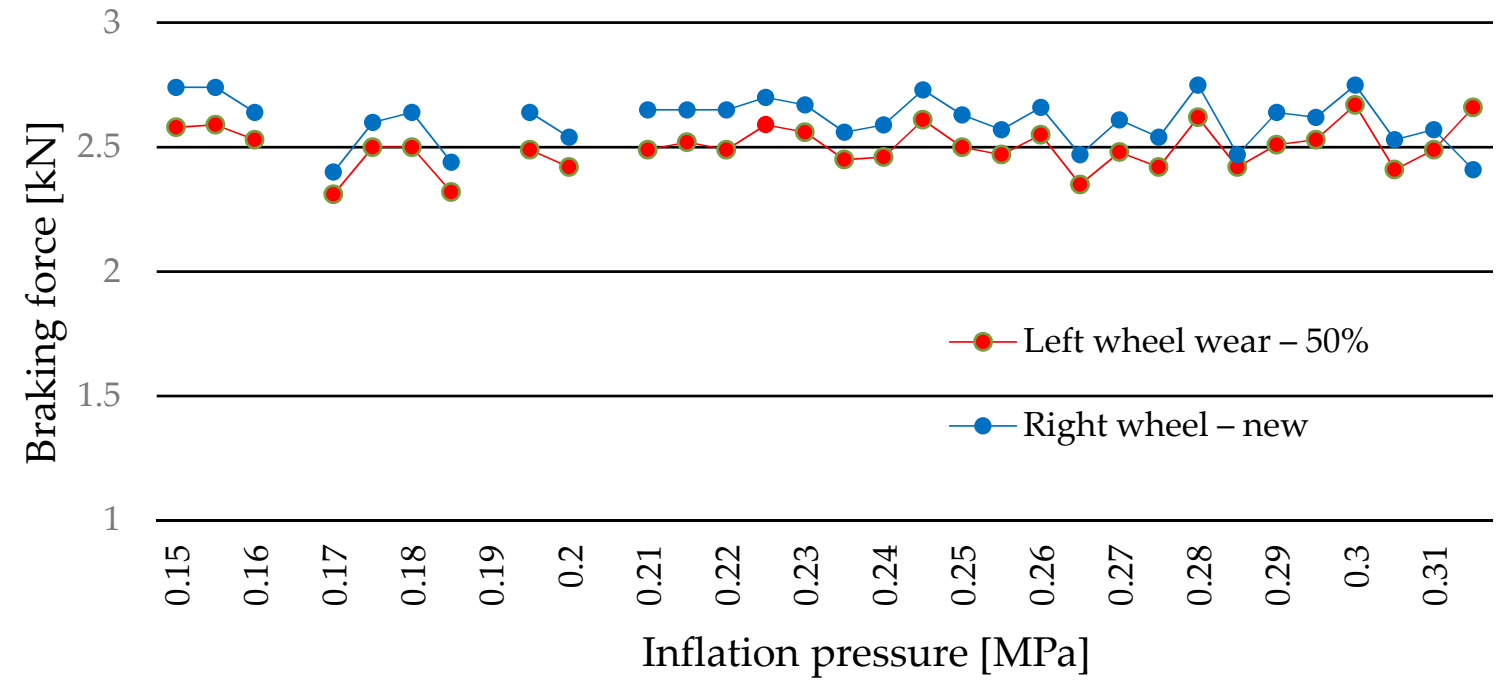

Figure 12. Breaking force in the function of tire inflation pressure-OPEL ASTRA, loaded.

\section{Conclusions}

The basic assumption of this study was to assess the impact of the technical condition of tires on road safety.

After approximately 140 measurements of braking forces of the front axle wheels on a roller station of two similar vehicles with different tire tread wear, different inflation pressure, and different payloads, the following conclusions can be drawn:

- There is no clear trend of any decrease or increase in braking power depending on the inflation pressure of the tires in the tested pressure range.

- $\quad$ Tire tread wear has a virtually unpredictable effect on the braking force obtained.

- The additional payload of vehicles does not affect the increase or decrease in braking force, depending on the inflation pressure and tread wear level.

After carrying out the above tests, it can be concluded that with the use of a roller station, no decisive dependency can be seen between the tread wear and tire inflation pressure and road traffic 
safety. A real assessment could be made during road tests in real conditions in different driving conditions (torsion, braking), at different vehicle speed ranges, and in different atmospheric conditions.

It is also possible to draw a general conclusion that a roller station at a vehicle inspection station is more useful for checking the efficiency of the entire braking system, rather than for checking the efficiency or quality of the tires. It should therefore be stated that the organoleptic inspection of tires is a very important element of vehicle testing at vehicle inspection stations in the aspect of road traffic safety.

The above conclusions should be taken into account in formulation of legal requirements for cars testing, especially cars with substantial mileage.

Future research: The studies performed on the regular inspection line do not permit us to evaluate effects of tire wear on all aspects of car behavior on the road. Consequently, additional research is needed in the direction of introducing modifications into vehicle inspection unit, as well as looking for completely different methods of car performance evaluation.

Also, data obtained from standard car inspection unit are not sufficient to detect the effect of tire condition on the fuel consumption. Studies in this direction will be continued.

Author Contributions: Conceptualization, K.T. and O.O.; methodology, A.W. and R.S.; validation, A.W. and A.G.; investigation, A.G. and R.S.; writing-original draft preparation, K.T. and O.O.; funding acquisition, A.G. All authors have read and agreed to the published version of the manuscript.

Funding: The authors wish to express gratitude to Lublin University of Technology for financial support given to the present publication (Arkadiusz Gola). The research was carried out under financial support obtained from the research subsidy of the Faculty of Engineering Management (WIZ) of Bialystok University of Technology. From the grant No. WZ/WIZ/4/2019 (Olga Orynycz, Andrzej Wasiak).

Conflicts of Interest: The authors declare no conflict of interest. The funders had no role in the design of the study; in the collection, analyses, or interpretation of data; in the writing of the manuscript; or in the decision to publish the results.

\section{References}

1. Tan, J.; Xiao, J.; Zhou, X. Market equilibrium and welfare effects of a fuel tax in China: The impact of consumers' response through driving patterns. J. Environ. Econ. Manag. 2019, 93, 20-43. [CrossRef]

2. Kim, N.; Rousseau, A.; Rask, E. Vehicle-level control analysis of 2010 Toyota Prius based on test data. Proc. Inst. Mech. Eng. Part D J. Automob. Eng. 2012, 226, 1483-1494. [CrossRef]

3. Tucki, K.; Orynycz, O.; Swic, A.; Mitoraj-Wojtanek, M. The Development of Electromobility in Poland and EU States as a Tool for Management of $\mathrm{CO}_{2}$ Emissions. Energies 2019, 12, 1-22.

4. Silva, C.A.M. Grid Electrified Vehicles: Performance. Design and Environmental Impacts, 1st ed.; Nova Science Publishers: New York, NY, USA, 2013; pp. 20-283.

5. Tucki, K.; Mruk, R.; Orynycz, O.; Wasiak, A.; Botwinska, K.; Gola, A. Simulation of the Operation of a Spark Ignition Engine Fueled with Various Biofuels and Its Contribution to Technology Management. Sustainability 2019, 11, 2799. [CrossRef]

6. Tucki, K.; Mruk, R.; Orynycz, O.; Wasiak, A.; Swic, A. Thermodynamic Fundamentals for Fuel Production Management. Sustainability 2019, 11, 4449. [CrossRef]

7. Bokhari, A.; Chuah, L.F.; Yusup, S.; Klemeš, J.J.; Akbar, M.M.; Kamil, R.N.M. Cleaner production of rubber seed oil methyl ester using a hydrodynamic cavitation: Optimization and parametric study. J. Clean. Prod. 2016, 4, 31-41. [CrossRef]

8. Periasamy, K.; Vijayan, S. Design and development of air-less car tire. Int. J. Adv. Eng. Technol. 2014, 7, 1312-1317.

9. Kannan, D.; Diabat, A.; Shankar, K.M. Analyzing the drivers of end-of-life tire management using interpretive structural modeling (ISM). Int. J. Adv. Manuf. Technol. 2014, 9, 1603-1614. [CrossRef]

10. Nazarko, J.; Czerewacz-Filipowicz, K.; Kuźmicz, A.K. Comparative analysis of the Eastern European countries as participants of the new silk road. J. Bus. Econ. Manag. 2017, 18, 1212-1227. [CrossRef]

11. Bignozzi, M.C.; Sandrolini, F. Tyre rubber waste recycling in self-compacting concrete. Cem. Concr. Res. 2006, 4, 735-739. [CrossRef]

12. Koishi, M.; Govindjee, S. Inverse design methodology of a tire. Tire Sci. Technol. 2001, 3, 155-170. [CrossRef] 
13. Olatunbosun, O.A.; Bolarinwa, O. FE simulation of the effect of tire design parameters on lateral forces and moments. Tire Sci. Technol. 2004, 3, 146-163. [CrossRef]

14. 2018 Road Safety Statistics: What is Behind the Figures? European Commission-Fact Sheet. Available online: https://europa.eu/rapid/press-release_MEMO-19-1990_en.htm (accessed on 26 October 2019).

15. Mohan, A.; Dutta, S.; Madav, V. Characterization and upgradation of crude tire pyrolysis oil (CTPO) obtained from a rotating autoclave reactor. Fuel 2019, 250, 339-351. [CrossRef]

16. Tire Recycling by Continuous Pyrolysis. Available online: https://reoil.pl/oferta/ (accessed on 26 October 2019).

17. Amari, T.; Themelis, N.J.; Wernick, I.K. Resource recovery from used rubber tires. Resour. Policy 1999, 3, 179-188. [CrossRef]

18. Ferrer, G. The economics of tire manufacturing. Conserv. Recycl. 2007, 4, 1-30.

19. Lee, S.J.; Lee, H.A.; Yi, S.I.; Kim, D.S.; Yang, H.W.; Park, G.J. Design flow for the crash box in a vehicle to maximize energy absorption. Proc. Inst. Mech. Eng. Part D J. Automob. Eng. 2013, 227, 179-200. [CrossRef]

20. Barroso, A.; Giarratana, M.S.; Pasquini, M. Product portfolio performance in new foreign markets: The EU trademark dual system. Res. Policy 2019, 48, 11-21. [CrossRef]

21. The United Nations Economic Commission for Europe (UNECE). Transport. Available online: http: //www.unece.org/trans/welcome.html (accessed on 30 November 2019).

22. Study on Some Safety-Related Aspects of Tyre Use. Available online: https://op.europa.eu/en/publicationdetail/-/publication/f3f32f73-7b42-4dda-b830-b3bd48090cfb (accessed on 30 November 2019).

23. Kim, S.; Park, H.; Moon, B.; Sung, K.; Koo, J.M.; Seok, C.S. The prediction methodology for tire's high speed durability regulation test using a finite element method. Int. J. Fatigue 2019, 118, 77-86. [CrossRef]

24. Zakład Produkcji Granulatu Gumowego. Available online: http://orzelsa.com/pl/zaklad-produkcji-granulatugumowego/ (accessed on 26 October 2019).

25. Castillo-Manzano, J.I.; Castro-Nuño, M.; Fageda, X. Exploring the relationship between truck load capacity and traffic accidents in the European Union. Transp. Res. Part E Logist. Transp. Rev. 2016, 88, 94-109. [CrossRef]

26. Olszewski, P.; Szagała, P.; Wolański, M.; Zielińska, A. Pedestrian fatality risk in accidents at unsignalized zebra crosswalks in Poland. Accid. Anal. Prev. 2015, 84, 83-91. [CrossRef]

27. Polish National Police. Road Traffic Office. Road Accidents in Poland in 2017. Available online: http:// statystyka.policja.pl/st/ruch-drogowy/76562.Wypadki-drogowe-raporty-roczne.html (accessed on 26 October 2019).

28. Regulation No 117 of the Economic Commission for Europe of the United Nations (UN/ECE) - Uniform Provisions Concerning the Approval of Tyres with Regard to Rolling Sound Emissions and to Adhesion on Wet Surfaces and/or to Rolling Resistance. Available online: https://eur-lex.europa.eu/legal-content/EN/TXT/ ?qid=1544800715965\&uri=CELEX:42011X1123(03) (accessed on 26 October 2019).

29. Proposal for a Council Decision on the Accession of the European Community to United Nations Economic Commission for Europe Regulation No 106 Concerning the Approval of Pneumatic Tyres for Agricultural Vehicles and Their Trailers. Available online: https:/eur-lex.europa.eu/legal-content/EN/TXT/?uri=CELEX\% 3A52000PC0160 (accessed on 26 October 2019).

30. Tyre Regulations. Available online: https://tpmszone.co.uk/tpms-information/regulations/ (accessed on 26 October 2019).

31. Uniform Provisions Concerning the Approval of: Wheels for Passenger Cars and Their Trailers. Available online: https://www.interregs.com/catalogue/details/ece-124/regulation-no-124-00/wheels-passenger-cars/ (accessed on 26 October 2019).

32. SAE J267 Wheels/Rims_-Truck and Bus-Performance Requirements and Test Procedures for Radial and Cornering Fatigue. Available online: https://www.sae.org/standards/content/j267_201411/ (accessed on 26 October 2019).

33. Janiszewski, J. Diagnostic utility vehicles in the Vehicle Inspection Station. Electr. Eng. 2015, 81, $205-211$.

34. Al-Saleh, K.S. Productivity improvement of a motor vehicle inspection station using motion and time study techniques. J. King Saud Univ. Eng. Sci. 2011, 23, 33-41. [CrossRef]

35. Żurowski, W.; Różycka, A. Analysis of technical safety requirements during diagnostic and maintenance car vehicles with all limit means for 3.5 t. Autobusy 2017, 6, 485-490. 
36. Burdzik, R.; Warczek, J. The influence of tyre pressure and vehicle load on evaluation of brake system effectiveness by vehicles services stations items. Sci. J. Sil. Univ. Technol. Ser. Transp. 2010, 66, 15-24.

37. Tarkowski, S.; Mikus, D. Vehicle's deceleration in selected terms of motion. Autobusy 2017, 17, 438-441.

38. Caban, J.; Droździel, P.; Barta, D.; Liščák, S. Vehicle tire pressure monitoring systems. Diagnostyka 2014, 15, $11-14$.

39. Tarkowski, S.; Mikus, D.; Lotko, W. Age and technical condition of car tires and its impact to deceleration during braking maneuver. Autobusy 2017, 6, 440-444.

40. Kałuża, R. Influence of the type and degree of wear of a car tire on the result of the static puncture test. Logistyka 2015, 4, 1397-1404.

41. Kamiński, T.; Pelc, J. Pneumatic tires failures and communication accidents. Logistyka 2015, 5, 969-974.

42. Bęczkowska, S.; Korzeb, J.; Koziak, S.; Opala, M.; Weyssenhoff, A. Non-uniformities and defects in materials of passenger car tyres-selected issues. Wars. Univ. Technol. Transp. 2018, 121, 9-20.

43. Kotyk, M.; Piotrowski, M. Influence of gas temperature and pressure on radial stiffness vehicle tyres. Logistyka 2015, 4, 4176-4184.

44. Salehi, M.; Noordermeer, J.W.M.; Reuvekamp, L.A.E.M.; Dierkes, W.K.; Blume, A. Measuring rubber friction using a Laboratory Abrasion Tester (LAT100) to predict car tire dry ABS braking. Tribol. Int. 2015, 131, 191-199. [CrossRef]

45. Chen, Z.; Xie, Z.; Zhang, J. Measurement of Vehicle-Bridge-Interaction force using dynamic tire pressure monitoring. Mech. Syst. Signal Process. 2018, 104, 370-383. [CrossRef]

46. Antona-Makoshi, J.; Mikami, K.; Lindkvist, M.; Davidsson, J.; Schick, S. Accident analysis to support the development of strategies for the prevention of brain injuries in car crashes. Accid. Anal. Prev. 2018, 117, 98-105. [CrossRef]

47. Prochowski, L. The analysis of a car motion path after collision with a concrete barrier. Maint. Reliab. 2011, 13, 71-80.

48. Huang, M.; Guibert, M.; Thévenet, J.; Fayolle, C.; Chaussée, T.; Guy, L.; Vanel, L.; Loubet, J.L.; Sotta, P. A new test method to simulate low-severity wear conditions experienced by rubber tire materials. Wear 2018, 410, 72-82. [CrossRef]

49. Nguyen, V.H.; Zheng, D.; Schmerwitz, F.; Wriggers, P. An advanced abrasion model for tire wear. Wear 2018, 396-397, 75-85. [CrossRef]

50. Gent, A.N.; Walter, J.D. The Pneumatic Tire; US. DOT HS 810561; National Highway Traffic Safety Administration: Washington, DC, USA, 2006; pp. 1-707. Available online: https://www.nhtsa.gov/search? keywords=DOT + HS +810561 (accessed on 17 December 2019).

51. Prochowski, L. Pojazdy Samochodowe. Mechanika Ruchu, 1st ed.; Wydawnictwa Komunikacji i Łacczności: Warszawa, Polska, 2016; pp. 255-289.

52. Prochowski, L.; Unarski, J.; Wach, W.; Wicher, J. Podstawy Rekonstrukcji Wypadków Drogowych, 1st ed.; Wydawnictwa Komunikacji i Łączności: Warszawa, Polska, 2014; pp. 133-216.

53. Wicher, J. Bezpieczeństwo Samochodów I Ruchu Drogowego, 1st ed.; Wydawnictwa Komunikacji i Łaczności: Warszawa, Polska, 2012; pp. 137-170.

54. General Director for National Roads and Motorways. Report on the Technical Condition of the Surface of the National Road Network Administered by the General Directorate for National Roads and Motorways. Wrocław Branch at the End of 2017. Available online: https://www.gddkia.gov.pl/pl/a/30240/ROK-2017 (accessed on 26 October 2019).

55. Heinrich, G.; Klüppel, M. Rubber friction, tread deformation and tire traction. Wear 2008, 265, $1052-1060$. [CrossRef]

56. Tiwari, A.; Miyashita, N.; Espallargas, N.; Persson, B.N.J. Rubber friction: The contribution from the area of real contact. J. Chem. Phys. 2018, 148, 224701. [CrossRef]

57. Krmela, J.; Krmelová, V. Dynamic Experiment of Parts of Car Tyres. Procedia Eng. 2017, 187, 763-768. [CrossRef]

58. Prajwowski, K.; Gołębiewski, W. Effect of tire type on braking distance at different outdoor temperatures. Autobusy 2017, 7, 109-112.

59. Merwe, N.A.; Els, P.S.; Žuraulis, V. ABS braking on rough terrain. J. Terramechanics 2018, 80, 49-57. [CrossRef]

60. Chang, Y.H.; Joo, B.S.; Lee, S.M.; Jang, H. Size effect of tire rubber particles on tribological properties of brake friction materials. Wear 2018, 394, 80-86. [CrossRef] 
61. Zöller, C.; Wagner, P.; Winner, H. Tires and vertical dynamics of wheeled mobile driving simulators. Transp. Res. Part F Traffic Psychol. Behav. 2017, 61, 69-83.

62. Kardas-Cinal, E.; Lozia, Z.; Więckowski, D. Comparison of the level of simulated vibrations acting on a child transported in a road car or a railway vehicle. Pr. Nauk. Politech. Warszawskiej Transp. 2016, 112, 153-163.

63. Angelo, C.M.; Machado, F.A.C.; Schön, C.G. Influence of tire sizes over automobile body spectrum loads and fatigue damage accumulation. Mater. Des. 2015, 67, 385-389. [CrossRef]

64. Kovalyov, V.; Morozov, D. Accident Mechanism Modeling for Failure of Tires in Motion. Transp. Res. Procedia 2017, 20, 355-360. [CrossRef]

65. Nyaaba, W.; Frimpong, S.; Anani, A. Fatigue damage investigation of ultra-large tire components. Int. J. Fatigue 2019, 119, 247-260. [CrossRef]

66. European Division of Cars into Classes by Size. Available online: https://autobooking.com/pl-pl/news/ europejski-podzial-samochodow-na-klasy-wedlug-wielkosci (accessed on 30 November 2019).

67. LibTech. Car Class-Division into Market Segments. Available online: http://libtech.com.pl/klasasamochodow-podzial-segmenty-rynkowe/ (accessed on 30 November 2019).

68. Audi. Wheels and Tires. Available online: https://www.audiwarszawa.pl/download/katalog-opon-i-kolaudi.pdf (accessed on 30 November 2019).

69. Citroën Tyres. Available online: https://www.citroen.co.uk/owner-services/maintenance/tyres (accessed on 30 November 2019).

70. Skoda Brochures. Available online: https://www.skoda.co.uk/discover/download-a-brochure (accessed on 30 November 2019).

71. Toyota Brochures. Available online: https://www.toyota.com/brochures/cars-minivan (accessed on 30 November 2019).

72. Fiat Brochures. Available online: https://www.fiatprofessional.com/brochure (accessed on 30 November 2019).

73. Peugeot Range. Available online: https://www.peugeot.co.uk/peugeot-model-range/ (accessed on 30 November 2019).

74. Original Equipment. Available online: https://www.continental-tyres.ie/car/why-continental/originalequipment (accessed on 30 November 2019).

75. Inter Cars. Tire Catalog. Available online: https://intercars.com.pl/pl/kategoria/359/ (accessed on 30 November 2019).

76. Car Specifications. Available online: https://www.autocentrum.pl/dane-techniczne/ (accessed on 30 November 2019).

77. Automobile Catalog. Available online: https://www.automobile-catalog.com/ (accessed on 30 November 2019).

78. Tire Selection Configurator. Available online: https://www.opony.com/opona-do/skoda (accessed on 30 November 2019).

79. Car Makes. Available online: https://www.wheel-size.com/size/ (accessed on 30 November 2019).

80. Tire Replacements. Available online: https://www.opony.com.pl/narzedzia/zamienniki-opon/ (accessed on 30 November 2019).

81. Devices for Diagnosing Pneumatic Braking Systems. Available online: https://trans.info/pl/urzadzenia-dodiagnozowania-pneumatycznych-ukladow-hamulcowych-56e170f9bfbba055760f387c-3168\# (accessed on 30 November 2019).

82. Ryme. Tire Tracks Gauge 3d Scanner. Available online: http://www.ryme.com/producto/escaner-de-huellasde-neumaticos/ (accessed on 30 November 2019).

(C) 2019 by the authors. Licensee MDPI, Basel, Switzerland. This article is an open access article distributed under the terms and conditions of the Creative Commons Attribution (CC BY) license (http://creativecommons.org/licenses/by/4.0/). 